http://jmscr.igmpublication.org/home/ ISSN (e)-2347-176x ISSN (p) 2455-0450 crossref DOI: https://dx.doi.org/10.18535/jmscr/v8i2.53

\title{
A Comparative Study of Thyroid Profile, Lactate Dehydrogenase and Uric Acid in Cases of Normotensive versus Hypertensive Pregnant Women
}

\author{
Authors \\ Ramya Nemani ${ }^{1}$, Kasibabu $\mathbf{A}^{2}$
}

\begin{abstract}
Introduction: Hypertension during pregnancy is a major health problem. It is one of the leading causes of perinatal morbidity and mortality Keeping in view of the severity of this condition, the present study attempts to evaluate the serum levels of thyroid hormones reflecting hormonal changes and activity of serum lactate dehydrogenase, along with serum uric acid measurements in understanding the pathophysiological basis of this condition in cases of hypertensive pregnant women in comparison to normal pregnant women.

Patients and Methods: 50 pre eclamptic women and 50 normotensive women are included in this study.

Results: Serum Thyroid stimulating hormone (TSH) levels are increased, T3 and T4 levels are not significant serum LDH and Uric acid are increased in pre-eclampsia.

Conclusion: It is concluded that serum TSH, LDH and Uric acid are reliable and inexpensive markers to predict the severity and outcome of pre-eclampsia.
\end{abstract}

\section{Introduction}

Hypertension during pregnancy is a major health problem. It is one of the leading causes of perinatal morbidity and mortality. It may manifest as gestational hypertension or chronic hypertension that was present even before pregnancy or chronic hypertension with superimposed preeclampsia or as preeclampsia which may lead to complications of eclampsia ${ }^{1}$. Among these, preeclampsia may lead to complications being more common. Nearly 10 per cent of cases of pregnancy may be encountered with hypertension as preeclampsia and eclampsia. Hypertension along with proteinuria and edema manifests clinically as preeclampsia. The latter is a multisystem disorder of pregnancy with potentially severe consequences to both mother and child. The condition is related to hypoxia in the placenta and endothelial dysfunction and leads to complications like intrauterine growth retardation, prematurity or even causing death of fetus ${ }^{2}$. Sometimes, preeclampsia may progress to eclampsia, which is a form of hypertensive disorder of pregnancy, with conclusions.

It has long been recognised that maternal thyroid hormone excess or deficiency can influence maternal and fetal outcome at all stages of pregnancy. ${ }^{3,4}$ Owing to various changes in thyroid profile of patients with preeclampsia and in normal pregnancy, as attempt is made to compare the serum levels of T3, T4, TSH in such cases, in the present study.

Hypertension in pregnancy may lead to endothelial dysfunction resulting in mild to moderate angiopathy of target organs leading to excessive leakage of lactate dehydrogenase (LDH) in serum. ${ }^{5}$ This enzyme being intracellular enzyme in the 
present study is proposed to use to assess the extent of cellular death and severity of condition pregnancy induced hypertensive women. ${ }^{6}$

Uric acid being a marker of oxidative stress is proposed to mediate altered vascular function and inflammation. ${ }^{7}$ Also, renal handling of uric acid is complex and involves certain phases leading to its net urinary excretion. Thus, decrease in renal clearance, secondary to disproportionate fall in glomerular filtration rate may lead to alteration in serum uric acid measures. ${ }^{7,8}$ The present study as an attempt will be carried out to critically appraise the levelsof serum uric acid in the severity of the condition in hypertensive preeclamptic patients compared to normal pregnant women.

Keeping in view of the severity of this condition, the present study attempts to evaluate the serum levels of thyroid hormones reflecting hormonal changes and activity of serum lactate dehydrogenase, along with serum uric acid measurements in understanding the pathophysiological basis of this condition in cases of hypertensive pregnant women in comparison to normal pregnant women.

\section{Patients and Methods}

Case controlstudy was conducted between June 2017 to September 2019 in the Department of Biochemistry, King George Hospital, Visakhapatnam.100 patients with age group 19 to 35 years were selected. Patients with pre-eclampsia attending OP or admitted in the department of obstetrics and Gynaecology. Subjects are divided into two groups, fulfilling inclusion and exclusion criteria.

GROUP A: 50 Normotensive women

GROUP B: 50 Preeclampsia women

Data Collection: After proper Institutional Ethical Clearance and informed written consent from the participants. Every effort was made not to disclose the identity of participants. A detailed family and medical history of all the childbearing women with gestational age 24 weeks or more admitted with the features of HDP was recorded followed by a thorough clinical examination. Systolic and diastolic blood pressure of all the participants was carefully recorded every four hours. Blood pressure was measured in both arms and one with higher value was taken as the blood pressure of record. Korotkoff phase $\mathrm{V}$ readings were used for diastolic readings. Urine analysis was done in all subjects to measure the degree of proteinuria and to differentiate patients with gestational hypertension from preeclampsia. The degree of proteinuria was measured by dipstick and graded as Trace to $4+$ (Trace, $\quad 0.1 \mathrm{gm} / \mathrm{L} ; 1+, \quad 0.3 \mathrm{gm} / \mathrm{L} ; 2+, \quad 1 \mathrm{gm} / \mathrm{L} ; 3+$, $3.0 \mathrm{gm} / \mathrm{L} ; 4+, 10 \mathrm{gm} / \mathrm{L})$. At the same time blood was taken from the ante-cubital vein using a sterile needle and syringe early in the morning after overnight fasting for serum calcium measurement. Blood samples were allowed to clot and then centrifuged at 3000 revolutions per minute for 10 minutes. Serum T3,T4 and TSH were measured in an automated hormone analyzer by chemiluminescence method, serum Lactate Dehydrogenase by enzyme kinetic method, and serum uric acid by uricase method.

\section{Inclusion Criteria}

1) Pregnant women at or beyond 24 weeks of gestation.

2) Pregnant women with pre-eclampsia, criteria are Systolic blood pressure of $\geq 140 \mathrm{mmHg}$, diastolic blood pressure of $90 \mathrm{mmHg}$ and presence of significant proteinuria. (3+)

3) Age between 19 to 35 years.

4) The healthy pregnant women are taken as controls.

\section{Exclusion Criteria}

1) Patients in active labour.

2) Patients with essential hypertension.

3) Patients with acute or chronic liver diseases.

4) Patients with DM and Gout.

\section{Results}

\section{Serum T3 levels of cases and controls}

The [mean $\pm \mathrm{SD}$ ] serum T3 of the cases $131.26 \pm 36.758$ and of the controls $144.08 \pm 36.47$. There was no statistical difference in serum T3 levels between the two groups. 
Graph 1: Serum T3 levels of study cases and controls

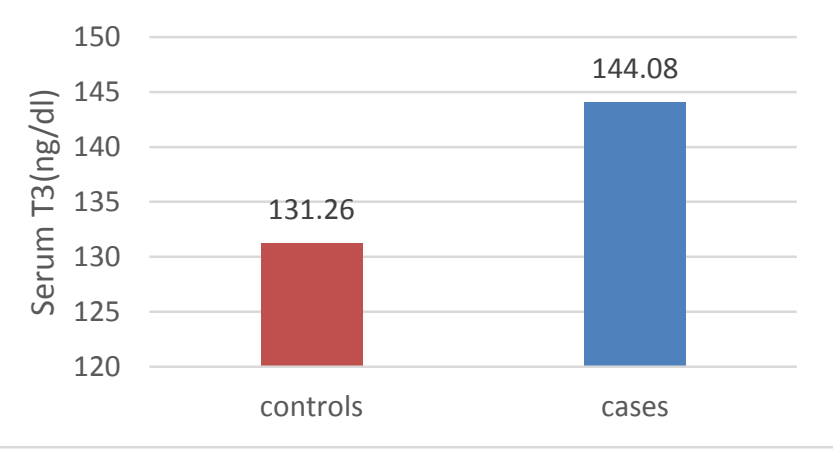

\section{Serum T4 levels of cases and controls}

The [mean \pm SD] serum T3 of the cases $6.815 \pm 3.624$ and of the controls $6.516 \pm 1.682$. There was no statistical difference in serum T4 levels between the two groups.

Graph 2: Serum T4levels of study cases and controls

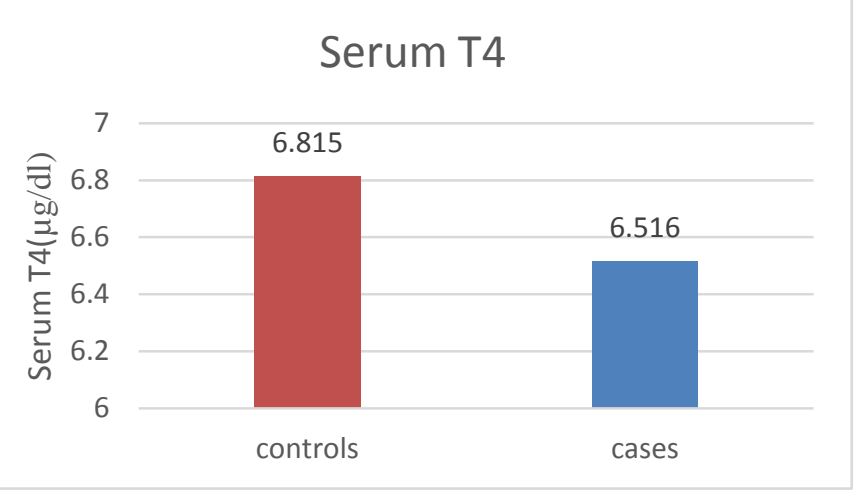

\section{Serum TSH levels of cases and controls}

The [mean \pm SD] serum T3 of the cases $4.746 \pm 1.241$ and of the controls $1.544 \pm 0.448$. There was a statistical difference in serum TSH levels between the two groups.
Graph 3: Serum TSH levels of study cases and controls

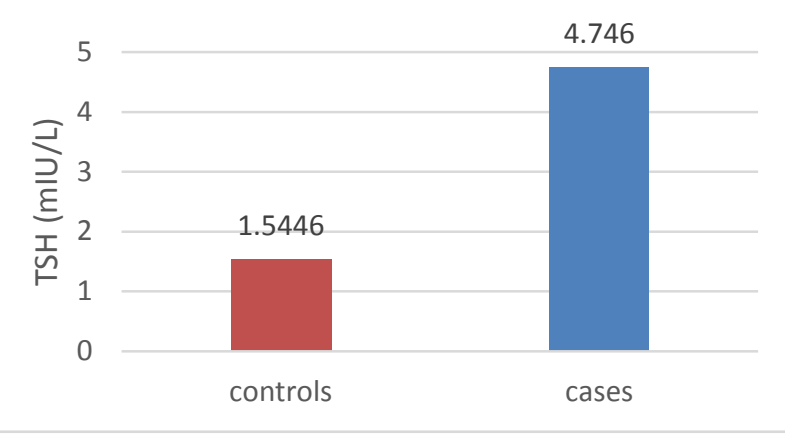

\section{Serum LDH levels of cases and controls}

The [mean \pm SD] serum LDH of the cases $906.32 \pm 246.9$ and of the controls $351.32 \pm 87.85$. There was a statistical difference in serum $\mathrm{LDH}$ levels between the two groups.

Graph 4: Serum LDH levels of study cases and controls

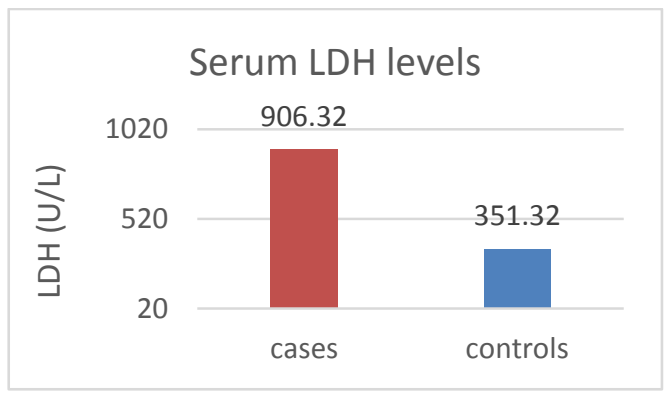

Serum Uric Acid levels of cases and controls

The [mean $\pm \mathrm{SD}$ ] serum Uric Acid of the cases $6.594 \pm 0.936$ and of the controls $3.008 \pm 0.586$. There was a statistical difference in serum Uric acid levels between the two groups.

Graph 5: Serum Uric acid levels of study cases and controls

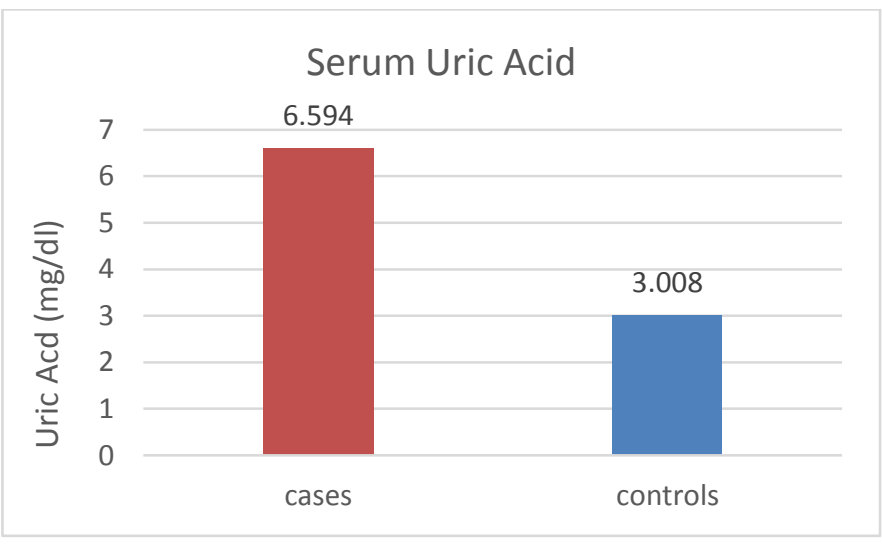


Table 1: Correlation of serum T3 with blood pressure

\begin{tabular}{|l|c|c|c|}
\hline Parameter & $\begin{array}{c}\text { 'r' } \\
\text { value }\end{array}$ & $\begin{array}{c}\text { 'p' } \\
\text { value }\end{array}$ & $\begin{array}{c}\text { Statistical } \\
\text { Significance }\end{array}$ \\
\hline $\begin{array}{l}\text { Systolic blood pressure } \\
\text { (mm Hg) }\end{array}$ & -0.321 & $<0.05$ & Significant \\
\hline $\begin{array}{l}\text { Diastolic blood pressure } \\
\text { (mm Hg) }\end{array}$ & -0.451 & $<0.05$ & Significant \\
\hline
\end{tabular}

There is statistically significant negative correlation between blood pressure and serum T3 levels. As blood pressure increases, serum T3 levels decrease.

Graph 6: Correlation of serum T3 with systolic blood pressure

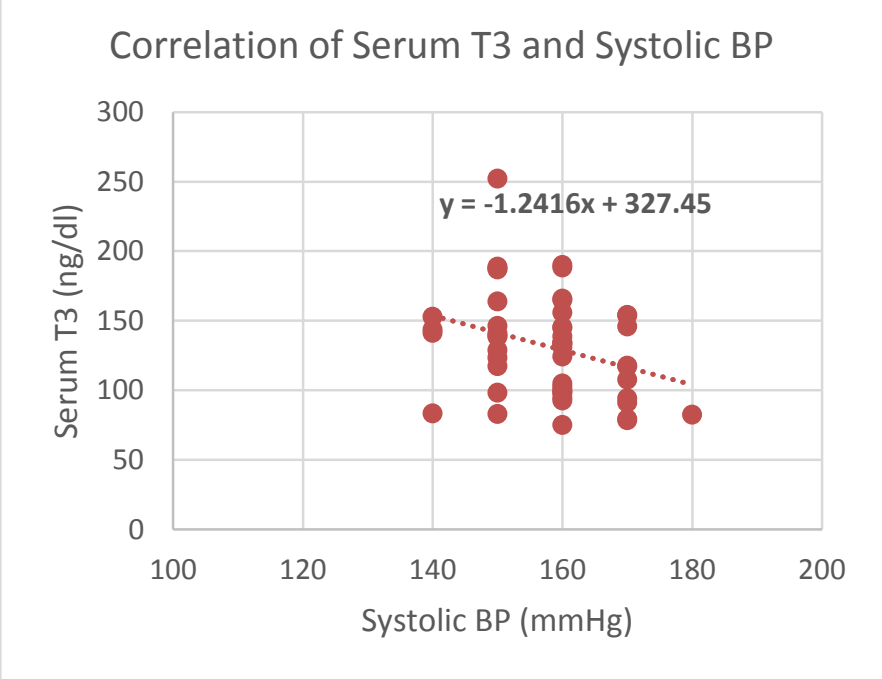

Table 2: Correlation of serum uric acid with blood pressure

\begin{tabular}{|l|c|c|c|}
\hline Parameter 'r' value & 'p' value & $\begin{array}{c}\text { Statistical } \\
\text { Significance }\end{array}$ \\
\hline $\begin{array}{l}\text { Systolic blood } \\
\text { pressure (mm Hg) }\end{array}$ & 0.321 & $<0.001$ & Significant \\
\hline $\begin{array}{l}\text { Diastolic blood } \\
\text { pressure (mm Hg) }\end{array}$ & 0.033 & $>0.05$ & Not Significant \\
\hline
\end{tabular}

- There is a statistically significant correlation between systolic blood pressure and serum uric acid levels. ( $\mathrm{r}=0.321)$.

- There is statistically no significant correlation between diastolic blood pressure and serum uric acid levels. $(\mathrm{r}=0.033)$
Graph 7: Correlation of serum uric acid with systolic blood pressure

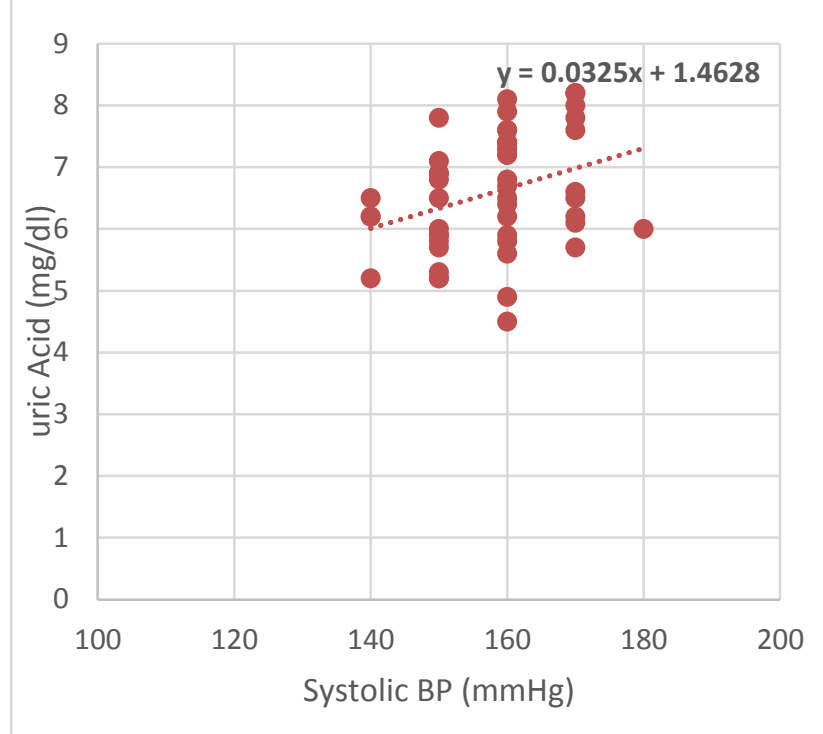

Table 3: Correlation of serum LDH with blood pressure

\begin{tabular}{|l|c|c|c|}
\hline Parameter 'r' & $\begin{array}{c}\text { 'p' } \\
\text { value }\end{array}$ & $\begin{array}{c}\text { Statistical } \\
\text { Significance }\end{array}$ \\
\hline $\begin{array}{l}\text { Systolic blood } \\
\text { pressure (mm Hg) }\end{array}$ & 0.400 & $<0.001$ & Significant \\
\hline $\begin{array}{l}\text { Diastolic blood } \\
\text { pressure (mm Hg) }\end{array}$ & 0.333 & $<0.001$ & Significant \\
\hline
\end{tabular}

- There is a statistically significant correlation between systolic blood pressure and serum LDH levels. ( $\mathrm{r}=0.400$ )

- There is a statistically significant correlation between diastolic bloodpressure and serum LDH levels. $(r=0.333)$

Graph 8: Correlation of serum LDH with systolic blood pressure

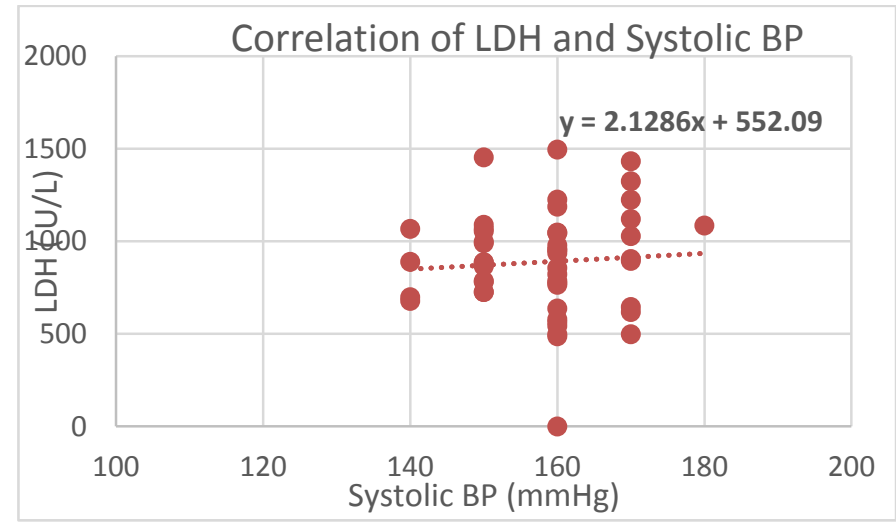




\section{Discussion}

The [mean $\pm \mathrm{SD}$ ] systolic blood pressure in cases was $158.0 \pm 9.258 \mathrm{~mm} \mathrm{Hg}$ and in controls 112.4 \pm $9.806 \mathrm{~mm} \mathrm{Hg}$. The [mean $\pm \mathrm{SD}$ ] diastolic blood pressure in cases was $97.80 \pm 7.89 \mathrm{~mm} \mathrm{Hg}$ and in controls $73.80 \pm 1.56 \mathrm{~mm} \mathrm{Hg}$. There is a high statistical significance in the blood pressure, both systolic and diastolic, between the twogroups. The results in the present study are in accordance with the studies of Afroz R et al. And Bairwa R et al.

The [mean $\pm \mathrm{SD}$ ] serum T3 levels in cases were $131.26 \pm 36.75 \mathrm{mg} / \mathrm{dl}$ and in controls $144.08 \pm 36.47$ $\mathrm{mg} / \mathrm{dl}$. The results of the present study show that there is statistically no significant difference between the two groups. These findings are in concordance with Anitha K Satyanarayan et al. and Sardana D et al.

The mean \pm SD serum $\mathrm{T} 4$ levels in cases were $6.815 \pm 3.624$ and in controls $6.516 \pm 1.682$.The results of the present study show that there is statistically no significant difference between the two groups. These findings are in concordance with Anitha K Satyanarayan et al and Sardana D et al.

The mean \pm SD serum TSH levels in cases were $4.746 \pm 1.241$ and in controls 1.5446 \pm 0.448 The results of the present study are in concordance with Anitha K Satyanarayanan et al., L Harshavardhan et al., Kumar et al, Lao et al, Tehrani et al, Larijani et al., Sardana D et al which have shown biochemical hypothyroidism in preeclampsia.

The [mean \pm SD] serum LDH of the cases $906.32 \pm 246.9$ and of the controls $351.32 \pm 87.85$. The results of the present study show that there is a statistically significant difference between the two groups. These findings were in accordance with a study done by Qublan et al. and Kozic et al.

The $[$ mean \pm SD] serum Uric Acid of the cases $6.594 \pm 0.936$ and of the controls $3.008 \pm 0.586$. The results of the present study show that there is a statistically significant difference between the two groups. This finding is in accordance with the study done by Punthumapol et al. Gianni et al

It is found that as the systolic blood pressure increases, there is a decrease in the serum T3 values, indicating that the severe the preeclampsia, the lower are the values of serumT3. : uric acid has a positive correlation with the systolic blood pressure as compared with the diastolic blood pressure. As the systolic blood pressure increases serum uric acid also increases LDH has a positive correlation with the systolic blood pressure as compared with the diastolic blood pressure. As the systolic blood pressure increases, serum LDH increases.

\section{Limitations of the study}

The present study was conducted on a small group of childbearing women with pre-eclampsia. Further studies on a larger sample with longer follow up are needed to substantiate our findings before conclusions can be drawn on the utility of these parameters for the diagnosis and assessment of severity of preeclampsia.

\section{Conclusion}

This study estimated the serum levels of T3, T4, $\mathrm{TSH}, \mathrm{LDH}$ and Uric acid in 50 patients who are diagnosed with preeclampsia to assess the severity of the disease.

In this context, this study observed statistically significant numbers of pre-eclamptic women with elevated TSH levels. However, unlike TSH, the T3 and T4 levels are not statistically significant when compared to the control group.

Thyroid diseases are predisposing factors for the development of preeclampsia Pre-eclamptic patients with raised thyroid-stimulating hormone levels had a poor maternal and fetal outcome. Identification of thyroid abnormalities and appropriate measures might affect the occurrence and severity of the morbidity and mortality associated with preeclampsia.

LDH and Uric acid are significantly elevated in diagnosed cases of pre-eclampsia. It was concluded that $\mathrm{LDH}$ and uric acid are reliable and inexpensive markers to predict the severity and outcome of preeclampsia, and fetal growth retardation. 


\section{References}

1. Pregnancy hypertension in; Cunningham F, Lenovok, Blooms, Halh J, Giststrop L, Wenstram K, eds William obstetrics, $23^{\text {rd }}$ edition, McGraw Hill, New York 2011; PP 706-728.

2. Davrison J, Homuth V, Jeyabalan A, Conrad K, Kanumanchi A, Quaggin S et al. New aspects in the pathophysiology of preeclampsia. JAM SOC Nephrol 2004; 15:2440-2448.

3. Kumar Ashok, Ghosh B K, Murthy N S. Maternal thyroid hormonal status in preeclampsia. Ind J Med Sci. 2005; 59 (2):57-63.

4. Kharb S, Sardona D, Nanda S. Correlations of thyroid functions with severity and outcome of pregnancy. Ann Med Health Sci Res. 2013; 3:131-134.

5. Qublan H S, Amarun V, Bateinan O, AlShradeih J, Tahat Y, Awamlah L et al; LDH as a biochemical marker of adverse pregnancy outcome in severe preeclampsia. Med Sci marit 2005; 11:393-397.

6. Umasatyasri Y, Vani J, Sharita P. Role of $\mathrm{LDH}$ in preeclampsia-eclampsia as a prognostic marker. International Archives of Integrated medicine. 2015 September; 2 (9):88-93.

7. Tziotis J, Puchner A M, Ulachas G et al. Renal glomerular and tubular function in relation to hyperuricemia of preeclampsia and eclampsia. Br J Obstat Gynaecol 2002; 109:197-201.

8. Saleh F, Shukar-ud-din S, Boomro N, Serum Uric acid as predictor model for preeclampsia. Pak J Sung 2010; 26 (3): 246251.

9. Afroz R, Akhter QS, Sadia H, Sultana S. Serum lactate dehydrogenase levelin severe preeclampsia. J Bangladesh Soc Physiol. 2015; 10(2): 71-75.

10. Bairwa R, Iqbal S. Serum lactate dehydrogenase (LDH) level in mild and severe preeclampsia as a prognostic marker.
Int J Reprod Contracept Obstet Gynecol. 2018; 7(10): 3969-74.

11. Satyanarayan AK, Chandregowda BH, Hemberal M, Taklikar RH. Maternal thyroid profile in preeclampsia. Int J Med Sci Public Health. 2015; 4: 1401-03.

12. Sardana D, Nanda S, Kharb S. Thyroid hormones in pregnancy and preeclampsia. J Turk Ger Gynecol Assoc. 2009; 10 (3): 168171.

13. Harshavardhan L, Dariya SS, Sharma A, Verma L. Study of association of thyroid hormone in preeclampsia and normal pregnancy. J Assoc Physicians India. 2017; 65(11): 44-46.

14. Tehrani FR, Pakniyat H, Naji A, Asefzadeh S. Thyroid hormone variations in preeclampsia. Journal of Qazvan University of Medical Sciences. 2003; 24: 18-23.

15. Larijani B, Marsoosi V, Aghakhani S, Moradi A, Hashemipour S. Thyroid hormone alteration in preeclamptic women. Gynecol endocrine. 2004; 18: 97-100.

16. Qublan H, Ammarin V, Bataineh O, et al. Lactic dehydrogenase as a biochemical marker of adverse pregnancy outcome in severe pre-eclampsia. Med Sci Monit. 2005; 11(8): 393-97.

17. Kozic JR, Benton SJ, Hutcheson JA, et al. Abnormal liver function tests as predictors of adverse maternal outcomes in women with preeclampsia. J ObstetGynaecol Can. 2011; 33(10): 995-1004.

18. Punthumapol C, Kittichotpanich B. Serumcalcium magnesium and uric acid in preeclampsia. J Med Assoc Thai. 2008; 91(7): 968-73.

19. Bellomo G, Venanzi S, Saronio P, Verdura C, Narducci PL. Prognostic significance of serum uric acid in women with gestational hypertension. Hypertension. 2011; 58:70408. 